\title{
PENGARUH EARNINGS, RESIDUAL INCOME, ECONOMIC VALUE ADDED DAN OPERATION CASH FLOW TERHADAP RETURN SAHAM
}

\author{
Ronny Malavia Mardani \\ Fakultas Ekonomi Universitas Islam Malang \\ Jalan MT. Haryono 193 Malang
}

\begin{abstract}
This study intends to test of: first, the effect of earnings, residual income, economic value added, and Operation Cash Flow simultaneously on returns received by shareholders manufacturing companies listed on the Indonesia Stock Exchange and second the effect of earnings, residual income, economic value added, and Operation Cash Flow partially on returns received by shareholders manufacturing companies listed on the Indonesia Stock Exchange. This study uses linear regression to see the contribution of each independent variable in influencing stock returns. The population in this study are all manufacturing companies listed on the Indonesia Stock Exchange (BEI) in 2008-2011. Being sampled in this study was determined using purposive sampling method. With purposive sampling method found 40 companies that meet the criteria and deserves to be sampled. Based on the analysis it can be concluded simultaneously Earnings, Economic Value Added, Residual Income and Cash Flow Operation significant effect on the return. In partially, only Earnings and Cash Flow Operation significant effect on the return.
\end{abstract}

Keywords: keuntungan, pemasukan bersifat residual, penambahan nilai ekonomi, arus dana operasional, pengembalian.

Dalam pengambilan keputusan investasi,faktor kemampuan perusahan dalam menghasilkan laba dan kepastian memperoleh hasil dalam investasi merupakan hal yang sangat penting untuk diperhitungkan. Sehingga dalam berinvestasi, investor tentu akan menanamkan modalnya pada perusahaan yang dipandang mampu meningkatkan kekayaan baginya. Pengukuran kinerja perusahaan diperlukan untuk menentukan keberhasilan perusahaan dalam memberikan tingkat pengembalian (rate of return). Akan tetapi, ini bukanlah yang hal mudah untuk dilakukan.

Alat ukur yang dapat digunakan untuk mengukur kinerja perusahaan diantaranya adalah earnings, residual income, Economic Value Added (EVA) dan Operation Cash Flow.Earnings adalah laba bersih sebelum akun-akun luar biasa (extraordinary accounts) selama satu tahun buku sebagaimana tercantum dalam 
laporan laba rugi.Earnings diukur dengan satuan rupiah per lembar saham. Sedang Residual Income (RI) adalah net operating profit after tax (NOPAT) selama satu tahun buku dikurangi cost of capital yang dikalikan dengan net operating asset.

Selain itu, untuk mengukur kinerja perusahaan dapat pula menggunakan EVA. Konsep EVA ini didasarkan pada biaya modal rata-rata tertimbang (weighted average cost of capital). EVA sebagai alat ukur yang sesuai digunakan untuk menilai kinerja operasional karena secara fair juga mempertimbangkan tingkat pengembalian minimum yang diisyaratkan (required rate) untuk itu perlu dipahami dalam rumusan sederhana bahwa ukuran dari EVA adalah jika EVA>0 maka terjadi proses nilai tambah pada perusahaan, sementara EVA=0 menunjukkan posisi impas perusahaan, sebaliknya kondisi EVA $<0$ menunjukkan tidak terjadinya proses nilai tambah pada perusahaan, karena laba yang tersedia tidak bisa memenuhi harapan para penyandang dana (Widayanto, 1993:50)

Namun dalam menilai kinerja perusahaan tidak cukup hanya menggunakan laba akuntansi saja. Laba akuntansi tidak mempunyai makna riil apabila tidak di dukung oleh kemampuan perusahaan untuk menghasilkan kas. Simmamora (2000:488) menyatakan keunggulan laporan arus kas dapat digunakan untuk menilai likuiditas, menentukan kebijakan deviden dan mengevaluasi dari keputusan-keputusan kebijakan pokok yang menyangkut investasi dan pendanaan.

Berdasarkan latar belakang tersebut, yang menjadi rumusan masalah dalam penelitian ini adalah: apakah earnings,residual income, economic value added, danOperation Cash Flow berpengaruh secara simultan dan parsial terhadap returnsaham pada indusri manufaktur di BEI?

\section{Konsep Return}

Return merupakan hasil yang diperoleh dari investasi. Return dapat berupa return realisasi yang sudah terjadi atau Return ekspektasi yang belum terjadi tetapi yang diharapkan akan terjadi dimasa mendatang.Return realisasi (realized return) merupakan return yang telah terjadi. Return realisasi dihitung berdasarkan data 
historis. Return realisasi penting karena digunakan sebagi salah satu pengukur kinerja dari perusahaan. Return histori ini juga berguna sebagai dasar penentuan return ekspektasi (expected return) dan resiko dimasa mendatang.

Menurut Jogianto (1998:368) return saham atau hasil pengembalian saham merupakan pendapatan yang berhak diperoleh investor karena menginvestasikan dana dalam bentuk saham. Sebagai seorang investor yang rasional, tentunya hasil pengembalian saham sangat diperhatikan karena tingkat keuntungan atau kerugian dapat selalu dipantau guna memperoleh kepastian bisnis.

Kekayaan pemegang saham dapat dinilai dari return yang diterima pemegang saham atas investasi yang telah dilakukan di dalam perusahaan. Return yang diterima pemegang saham dapat berupa penerimaan dividen tunai ataupun adanya perubahan harga saham pada suatu periode (Ross et al., 2002).

\section{Konsep Earnings}

Earnings dihasilkan melalui proses akuntansi dan disajikan dalam laporan laba rugi. Pendapatan diakui pada saat perusahaan telah menerima pembayaran tunai ataupun belum menerima pembayaran tunai (accrual basis). Biaya yang berkaitan langsung dengan pendapatan diakui pada periode yang sama dengan pengakuan pendapatan. Biaya yang tidak berkaitan langsung dengan pendapatan akan diakui pada periode terjadinya (Yudhira, 2008). Pada penelitian ini earnings diukur dengan earning per share (EPS). EPS menandakan kemampuan perusahaan menghasilkan keuntungan bersih dari setiap lembar saham. Investor biasanya akan memilih perusahaan yang mamiliki kenaikan EPS dari tahun ke tahun (Frank, 2000:360).

Pendapatan perlembar saham adalah jumlah pendapatan yang diperoleh dalam satu periode untuk tiap lembar saham yang beredar. Informai mengenai pendapatan perlembar saham dapat digunakan oleh pimpinan perusahaan untuk menentukan deviden yang akan dibagikan (Baridwan, 2000:448). Sedang Widoatmodjo (2001:155) berpendapat bahwa Earning per share diperoleh dengan cara membagi keuntungan setelah dipotong pajak yang diperoleh emiten dengan jumlah saham yang beredar. Earnings adalah laba bersih sebelum akun-akun luar 
biasa (extraordinary accounts) selama satu tahun buku sebagaimana tercantum dalam laporan laba rugi. Earning diukur dengan satuan per lembar saham.

Berdasarkan beberapa pendapat diatas, dapat disimpulkan bahwa, laba perusahaan merupakan faktor penentu yang penting untuk menentukan harga pasar saham biasa, data laba per saham sangat diperlukan bagi perusahaan dan investor sebagai alat informasi yang sangat penting. EPS merupakan rasio untuk mengukur berapa besar laba bersih yang dihasilkan perusahaan untuk tiap lembar saham yang baru.

\section{Konsep Residual Income}

Halim dan Supomo (1996:140) mengemukakan bahwa Residual Income (RI) merupakan metode alternatif dalam penilaian prestasi pusat investasi yang diharapkan dapat mengatasi salah satu kelemahan metode ROI.Berdasarkan metode ini prestasi pusat investasi berdasarkan jumlah laba absolut yang diperolehnya.Residual Income (RI) dihitung dari laba dikurangi biaya modal. Jika prestasi pusat investasi dinilai berdasarkan ROI, manajer divisi akan menolak suatu rencana investasi yang akan menghasilakan ROI dibawah ROI yang diharapkan. Menurut metode Residual Income (RI) suatu rencana investasi akan diterima jika menghasilkan Residual Income (RI) yang positif, terlepas apakah jika dihitung ROInya lebih kecil dari ROI yang diharapkan.Sedangkan Garrison dan Norren (2000:527) menyatakan bahwa : Residual Incomemerupakan laba netto operasi yang diperoleh pusat investasi diatas tuntutan minimal pengembalian modal yang diharapkan.

Residual income merupakan variabel yang dikembangkan dari beberapa penelitian sebelumnya.Pada prinsipnya, variabel ini digunakan untuk mengukursejauhmana pencapaian net income melebihi target laba perusahaan. Oleh karena itu, residual income adalah laba residu yang menunjukkan kelebihan nilai net income di atas nilai normalnya (Yudhira, 2008)

Dengan demikian dapat disimpulkan bahwa Residual Income dapat diperoleh dengan mengurangkan biaya modal dari laba opersi sehingga dapat 
diketahui hasil netto yang diperoleh pusat inestasi atas tingkat pengembalian minimum atas aktiva operasi.

\section{Konsep Economic Value Added (EVA)}

Beberapa ahli mengemukakan pendapatnya tentang EconomicValue Added (EVA) dengan definisi yang berbeda-beda. Berikut ini adalah beberapa definisi Economic Value Added (EVA) menurut beberapa ahli yaitu: Pertama, Economic Value Added (EVA) merupakan indikator tentang adanya penambahan nilai dari suatu investasi (Agnes Sawir, 2003:48). Kedua, Economic Value Added (EVA) adalah suatu tolak ukur yang menggambarkan jumlah absolut dari nilai pemegang saham (Shareholder value) yang diciptakan (created) atau dirusak (destroyed) pada suatu periode tertentu, biasanya satu tahun (Tunggal, 2001:2). Dan ketiga, EconomicValueAdded (EVA) adalah tolak ukur kinerja keuangan dengan mengukur perbedaan antara pengembalian atas modal perusahaan dengan biaya modal (Young dan Stephen, 2001:5).

Economic Value Added (EVA) merupakan indikator tentang adanya penciptaan nilai dari suatu investasi yang secara sederhana dapat diartikan sebagai laba operasi setelah pajak (after tax operating income) yang dikurangi dengan total biaya modal (total cost of capital), dimana total biaya modal dihitung dengan cara mengalikan tingkat biaya modal dengan total biaya modal yang diinvestasikan.

Young dan O'Byrne (2001:19) mengemukakan bahwa "menerima penciptaan nilai sebagai tujuan utama perusahaan hanya merupakan suatu permulaan.Para maanjer juga harus dapat mengukur kemamapuan mereka dalam mencapainya". Menentukan kriteria pengukuran yang akan digunakan dan menentukan pedoman untuk mengintereprestasikan hasil adalah penting pada tahap awal merancang dan menetapkan EVA. Baru kemudian pengukuran data dikaitkan dengan kompensasi manajemen untuk menyatukan tujuan dari para manajer dan pemegang saham.

Utama (1997:11) mengemukakan:“EVA yang positif menandakan bahwa tingkat pengembalian yang dihasilkan melebihi tingkat biaya modal atau tingkat pengembalian yang diminta investor aatas investasi yang dilakukannya. Kedaan 
ini menunjukkan bahwa perusahaan berhasil menciptakan nilai (create value) bagi pemilik modal, konsisten dengan tujuan memaksimumkan nilai perusahaan. Sebaliknya EVA yang negative menendakan bahwa nilai perusahaan berkurang sebagai akibat tingkat pengembalian yang dihasilkan lebih rendah daripada tingkat pengembalian yang dituntut investor".

Kekuatan konsep EVA mengukur nilai perusahaan terletak pada penggunaan perhitungan biaya modal perusahaan. Dengan mengetahui berapa biaya modal yang dipergunakan dalam menjalankan operasinya, perusahaan akan menetapkan rate of return yang lebih tinggi yang menjamin peningkatan perusahaan. Ukuran dari EVA adalah jika EVA $>0$ maka terjadi proses nilai tambah pada perusahaan, apabila $E V A=0$ menunjukkan posisis impas perusahaan, sebaliknya kondisi $\mathrm{EVA}<0$, menunjukkan tidak terjadinya proses nilai tambah pada perusahaan, karena laba yang tersedia tidak memenuhi harapan para penyandang dana.

\section{Konsep Operation Cash Flow (Operating Cash Flow/OCF)}

Laporan arus kas (cash flows statement) melaporkan arus kas selama periode tertentu dan diklasifikasikan menurut aktivitas operasi (operatingactivities), aktivitas investasi (investing activities), dan aktivitas pendanaan (financing activities).Informasi arus kas berguna untuk menilai kinerja perusahaan dalam menghasilkan kas. Informasi arus kas juga meningkatkan daya banding pelaporan kinerja operasi berbagai perusahaan, karena dapat meniadakan pengaruh penggunaan perlakuan akuntansi yang berbeda terhadap transaksi dan kejadian yang sama. Dalam hal ini, jumlah arus kas dari aktivitas operasi (cash flow operation) merupakan indikator yang menentukan apakah perusahaan dapat menghasilkan arus kas yang cukup untuk melunasi pinjaman, memelihara kemampuan operasi perusahaan, membayar dividen, serta melakukan investasi baru tanpa mengandalkan pada sumber pendanaan dari luar.

Ancella dalam Rini (2009:24) berpendapat bahwa dalam menentukan saham mana yang dibeli, seorang investor hendaknya melihat dan perubahan laba serta 
tingkat cash flow perusahaan. Tingkat laba akan menunjukkan pertumbuhan investasi yang dilakukan dan tingkat cash flow mengindikasikan ukuran kegiatan operasi perusahaan. Hal ini mengakibatkan setiap publikasi informasi arus kas akan menimbulkan reaksi investor yang berdampak pula pada volume perdagangan saham serta permintaan an penawaran harga saham(Octora dkk, 2003:250).

Variabel Operation Cash Flow (operating cash flow/OCF) diukur berdasarkan nilai OCF yang tersaji dalam laporan arus kas.Operation Cash Flow (operating cash flow/OCF) dapat diambil dari laporan arus kas, yang merupakan salah satu unsur dalam laporan keuangan.

\section{Hipotesis}

$\mathrm{H}_{1}$ : Earnings, Residual Income, Economic Value Added, dan Operation Cash Flowberpengaruh signifikan terhadap returnsaham

$\mathrm{H}_{1 \mathrm{a}}$ : Earningsberpengaruh signifikanterhadap saham

$\mathrm{H}_{1 \mathrm{~b}}$ : Residual Income berpengaruh signifikanterhadap returnsaham

$\mathrm{H}_{1 \mathrm{c}}$ : Economic Value Added berpengaruh signifikanterhadap returnsaham

$\mathrm{H}_{1 \mathrm{~d}}$ : Operation Cash Flow berpengaruh signifikanterhadap returnsaham

\section{METODE}

Populasi dalam penelitian ini adalah seluruh perusahaan manufaktur yang listing di Bursa Efek Indonesia (BEI)tahun 2008-2011.Sedang sampel dalam penelitian ini ditentukan dengan menggunakan metode Purposive Sampling.Adapun kriteria yang dijadikan sampel dalam penelitian ini adalah sebagai berikut :

- Perusahaan yang dijadikan sampel dalam penelitian ini adalah termasuk dalam jenis perusahaan manufaktur

- Mempublikasikan laporan keuangan tahunan secara konsisten dari tahun 2008-2011 yang telah diaudit.

- Laporan keuangan yang telah diaudit dengan pendapat wajar tanpa pengecualian.

- Tahun buku berakhir pada tanggal 31 Desember. 
- Tidak sedang dalam proses delisting.

- Perusahaan yang mempunyai laba positif.

- Perusahaan tersebut memiliki data yang sesuai dengan kriteria dan lengkap terkait dengan variabel-variabel yang digunakan dalam penelitian ini.

\section{Operasional Variabel}

\section{Return Saham}

Return yang diterima oleh pemmegang saham adalah pengembalian yang diterima oleh pemegang saham atas investasi yang telah dilakukan, yang bisa berupa deviden kas dan selisih perubahan harga saham (capital gain/loss). Deviden kas yang digunakan adalah deviden yang dibagikan setelah tanggal laporan keuangan tahunan dipublikasikan sampai dengan tanggal publikasi laporan keuangan tahun berikutnya. Demikian juga dengan harga saham, mengikuti tanggal publikasi laporan keuangan.Return yang diukur dengan satuan persen. Penggunaan satuan persen untuk mengukur return bertujuan menyetarakan (ekuivalensi) dari semua saham yang diobservasi, yang mana saham-saham tersebut memiliki haraga yang berbeda-beda.

Rumus perhitungan tingkat pengembalian saham sebagai berikut:

Return saham $(\mathrm{K})=\mathrm{D}_{1}+\left(\mathrm{P}_{1}-\mathrm{P}_{\mathrm{t}-1}\right) / \mathrm{P}_{\mathrm{t}-1}$

\section{Dimana:}

$\mathrm{R} \quad=$ hasil pengembalian yang diharapkan

$\mathrm{D}_{1} \quad=$ devidentahun sekarang

$\mathrm{P}_{1} \quad$ = harga investasi sekarang

$\mathrm{P}_{\mathrm{t}-1} \quad=$ harga investasi yang sebelumya

\section{Earnings}

Earnings adalah laba bersih selama akun-akun luar biasa (extra ordinary accounts) selama satu tahun buku sebagaimana tercantum dalam laporan laba rugi.Earnings diukur dengan satuan perlembar saham.

Menentukan besarnya jumlah EPS yang dihitung dengan rumus:

EPS $=\frac{\sum \text { Lababersih }}{\sum \text { LembarSahamBeredar }}$ 


\section{Residual Income (RI)}

Residual income (RI) adalah net operating profit after tax (NOPAT) selam satu tahu buku dikurangi cash of capital yang dikalikan dengan net operating assets.Residual income diukur dengan satuan rupiah perlembar saham.

Laba operasi

Biaya modal (\%) X aktiva operasional

Pendapatan residu

$$
\begin{aligned}
& =R p \cdot x x x \\
& =\underline{R p \cdot x x x} \\
& =R p \cdot X x x
\end{aligned}
$$

\section{Economic Value Added (EVA)}

Economic value added (EVA) adalah selisih antara adjusted NOPAT selamasatu tahun buku dan capital charge, yang didasarkan cost of capital dikalikan dengan adjusted net operating assets. EVA disini sama dengan formula EVA yang menjadi paten Stewart (1991:222) rumus cara pengukuran ecomonic value added adalah:

EVA $=$ EBIT-Tax-WACC

Dimana:

EVA = economic value added (rupiah)

$\mathrm{EBIT}=$ laba sebelum bunga dan pajak

Biaya modal rata-rata tertimbang (Weight Average Cost Of Capital/WACC) mencerminkan rata-rata biaya modal dimasa yang akan datang yang diharapkan. Sundjaja dan Barlian dalam Rini (2009:33) Biaya modal rata-rata tertimbang diperoleh dengan menimbang biaya dari setiap jenis modal tertentu sesuai dengan proporsinya pada struktur modal perusahaan yang dapat dirumuskan sebagai berikut:

$\mathrm{WACC}=\left(\mathrm{Kd}^{*} \mathrm{Wd}\right)+\left(\mathrm{Ke}{ }^{*} \mathrm{We}\right)$

Dimana:

$\mathrm{Kd} \quad=$ biaya modal hutang jangka panjang

$\mathrm{Wd}=$ komposisis hutang jangka panjang

Ke = biya ekuitas/modal saham

We $=$ komposisi ekuitas/modal saham 


\section{Operation Cash Flow (Operating Cash Flow/OCF)}

Kas operasi (Operating Cash Flow/OCF) adalah selisih bersih antara penerimaan dan pengeluaran kas dan setara kas yang berasal dari aktivitas operasi selama satu tahun buku, sebagaimana tercantum dalam laporan arus kas.Arus kas diukur dengan satuan rupiah perlembar saham.

Rumus:OCF= EAT+DEPRESIASI+BUNGA $(1-\mathrm{T})$

\section{Metode Analisis}

Analisis yang digunakan dalam penelitian adalah analisis kuantitatif yaitu dengan menggunakan model regresi linier berganda (multiple linear regression method).Model persamaan regresi yang digunakana dalam penelitian ini adalah : $\mathrm{Y}=\mathrm{a}+\mathrm{b} 1 \mathrm{X}_{1}+\mathrm{b} 2 \mathrm{X}_{2}+\mathrm{b} 3 \mathrm{X}_{3}+\mathrm{b} 4 \mathrm{X}_{4}+\mathrm{e}$

Dimana :

$\mathrm{Y}=$ Return

$\mathrm{a}=$ Konstanta

$\mathrm{b}=$ Koefisien regresi

$\mathrm{X}_{1}=$ Earnings

$\mathrm{X}_{2}=$ Economic Value Added

$\mathrm{X}_{3}=$ Residual Income

$\mathrm{X}_{4}=$ Operation Cash Flow

$\mathrm{e}=$ error

Sebelum dilakukan analisis regresi, terlebih dahulu dilakukan serangkaian pengujian yaitu normalitas dan uji asumsi klasik (Multikolinieritas dan Heteroskedastisitas).

\section{HASIL}

Populasi dalam penelitian ini adalah seluruh perusahaan yang listing di Bursa Efek Indonesia (BEI) tahun 2008-2011. Proses seleksi terhadap sampel penelitian dilakukan dengan menggunakan metode Purposive Sampling. Proses seleksi terhadap perusahaan sampel dapat dilihat pada tabel 1 sebagai berikut:

\section{Tabel 1}

Proses Seleksi Perusahaan Sampel 


\begin{tabular}{|c|l|c|}
\hline No & \multicolumn{1}{|c|}{ Uraian } & Jumlah \\
\hline 1 & $\begin{array}{l}\text { Perusahaan yang listing di Bursa Efek Indonesia (BEI) tahun } \\
2008-2011\end{array}$ & 436 \\
\hline 2 & $\begin{array}{l}\text { Perusahaan tidak termasuk dalam jenis perusahaan } \\
\text { manufaktur }\end{array}$ & $(289)$ \\
\hline 3 & $\begin{array}{l}\text { Perusahaan termasuk dalam jenis perusahaan manufaktur } \\
\text { wajar dengan pengecualian }\end{array}$ & 147 \\
\hline 4 & $\begin{array}{l}\text { Laporan keuangan yang telah diaudit dengan pendapat } \\
\text { wajar tanpa pengecualian }\end{array}$ & 139 \\
\hline 6 & \begin{tabular}{l} 
Sedang dalam proses delisting \\
\hline 7
\end{tabular} & $\begin{array}{l}\text { Tidak sedang dalam proses delisting } \\
(4)\end{array}$ \\
\hline 9 & Perusahaan mempunyai laba negatif & $(87)$ \\
\hline 11 & $\begin{array}{l}\text { Serusahaan mempunyai laba positif } \\
\text { 2008-2011 }\end{array}$ & 48 \\
\hline 12 & $\begin{array}{l}\text { Perusahaan tidak memiliki kelengkapan data laporan } \\
\text { keuangan }\end{array}$ & $(8)$ \\
\hline 13 & Perusahaan memiliki kelengkapan data laporan keuangan & 40 \\
\hline
\end{tabular}

Berdasarkan tabel 1 dapat diketahui bahwa Perusahaan yang memenuhi kriteria dan layak untuk dimasukkan dalam sampel penelitian sebanyak 40 perusahaan.

\section{Statistik Deskriptif}

Sebelum dilakukan proses analisis lebih lanjut, terlebih dahulu disajikan statistik deskriptif atas data yang digunakan dalam penelitian ini.

Tabel 2

Statistik Deskriptif

(Data telah dtransformasikan dengan Logaritma Natural)

\begin{tabular}{|l|c|c|c|c|c|}
\hline & RETURN & EARN & RESIN & EVA & OCF \\
\hline Mean & 0.344508 & 5.069486 & 7.647642 & 6.017962 & 10.62925 \\
\hline Median & 0.146429 & 4.973130 & 10.44981 & 0.000000 & 11.86409 \\
\hline Maximum & 6.375000 & 9.772589 & 17.63314 & 17.49814 & 15.44495 \\
\hline Minimum & -0.957477 & 0.693147 & 0.000000 & 0.000000 & 0.000000 \\
\hline Std. Dev. & 0.835195 & 2.062549 & 6.311294 & 6.457165 & 4.464587 \\
\hline Observations & 160 & 160 & 160 & 160 & 160 \\
\hline
\end{tabular}

Return Saham

Berdasarkan tabel 2, Return Saham memiliki rata-rata sebesar 0.344508dengan nilai minimum sebesar -0.957477dan nilai maksimum sebesar 6.375000.Sedang standar deviasi Return Saham sebesar 0.835195. Rata-rata Return 
Sahamperusahaan sampel sebesar 0.344508ini menunjukkan bahwa sebagian besar perusahaan memiliki trend harga saham yang meningkat di sepanjang tahun 2008-2011, sehingga didapatkan return yang positif. Ini dibuktikan dengan standar deviasi return saham yang bertanda positif.

\section{Earnings (EARN)}

Berdasarkan tabel 2, Earningmemiliki rata-rata sebesar 5.069486dengan nilai minimum sebesar 0dan nilai maksimum sebesar 17.63314. Sedang standar deviasi Earningsebesar 6.311294. Rata-rata dan standar deviasiEarningyang bernilai positif mengindikasikan bahwa sebagian besar perusahaan mampu memperoleh laba positif atas per lembar saham yang dimilikinya.

\section{Residual Income (RESIN)}

Berdasarkan tabel 2, RESINmemiliki rata-rata sebesar 7.647642dengan nilai minimum sebesar 0dan nilai maksimum sebesar 17.63314.Sedang standar deviasi RESINsebesar 6.311294. Rata-rata dan standar deviasi RESINyang bernilai positif mengindikasikan bahwa perusahaan mendapatkan hasil netto positif yang diperoleh pusat investasi atas tingkat pengembalian minimum atas aktiva operasi yang dilakukan perusahaan.

\section{Economic Value Added (EVA)}

Berdasarkan tabel 2, EVA memiliki rata-rata sebesar 6.017962dengan nilai minimum sebesar 0dan nilai maksimum sebesar 17.49814. Sedang standar deviasi EVA sebesar 6.457165. Rata-rata EVA perusahaan sampel yang bernilai positif menunjukkan bahwa tingkat pengembalian yang dihasilkan melebihi tingkat biaya modal atau tingkat pengembalian yang diminta investor atas investasi yang dilakukannya. Keadaan ini menunjukkan bahwa perusahaan berhasil menciptakan nilai (create value) bagi pemilik modal, konsisten dengan tujuan memaksimumkan nilai perusahaan

\section{Operating Cash Flow (OCF)}


Berdasarkan tabel 2, OCF memiliki rata-rata sebesar 10.62925dengan nilai minimum sebesar 0dan nilai maksimum sebesar 15.44495. Sedang standar deviasi OCF sebesar 4.464587. Rata-rata OCF perusahaan sampel yang positif mengindikasikan bahwa sebagian besar perusahaan memiliki ukuran kegiatan operasi yang baik.

\section{PEMBAHASAN}

\section{Uji Normalitas}

Pengujian normalitas dilakukan dengan menggunakan Jarque-Bera. Hasil pengujian dapat dilihat pada Tabel 3 dan Gambar 1 di bawah ini:

Tabel 3

Uji Normalitas

(Data telah dtransformasikan dengan Logaritma Natural)

\begin{tabular}{|l|c|c|c|c|c|}
\hline & RETURN & EARN & EVA & RESIN & OCF \\
\hline Skewness & 3.149500 & 0.117978 & 0.243438 & -0.256746 & -1.554064 \\
\hline Kurtosis & 20.08024 & 2.605793 & 1.254467 & 1.314243 & 4.389695 \\
\hline Jarque-Bera & 2209.414 & 1.407165 & 21.89289 & 20.70301 & 77.27810 \\
\hline Probability & 0.000000 & 0.494809 & 0.000018 & 0.000032 & 0.000000 \\
\hline Observations & 160 & 160 & 160 & 160 & 160 \\
\hline
\end{tabular}

Gambar 1

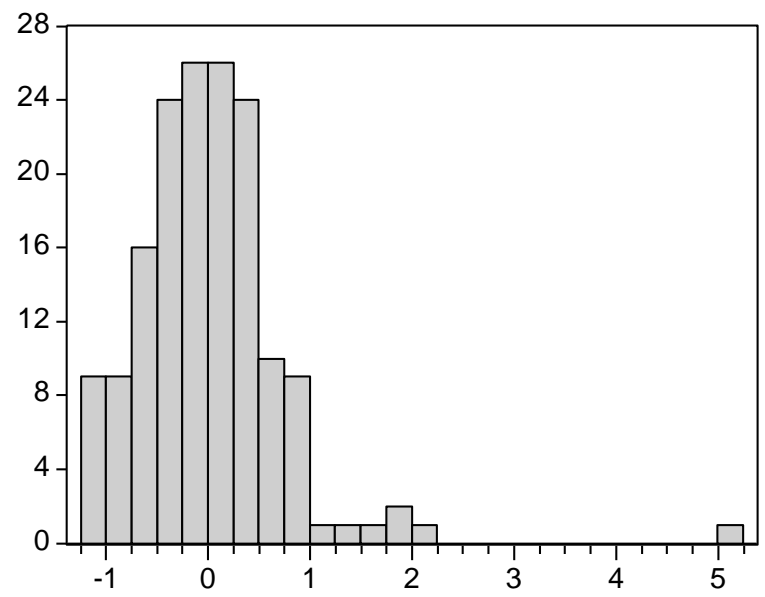

\begin{tabular}{|lr|}
\hline \multicolumn{2}{|l|}{ Series: Residuals } \\
Sample 1 160 \\
Observations 160 \\
Mean & $-2.17 \mathrm{E}-16$ \\
Median & -0.025550 \\
Maximum & 5.210620 \\
Minimum & -1.201767 \\
Std. Dev. & 0.735737 \\
Skewness & 2.518151 \\
Kurtosis & 17.72854 \\
& \\
Jarque-Bera & 1615.295 \\
Probability & 0.000000 \\
\hline
\end{tabular}

Data terdistribusi normal bila nilai Jarque-Beralebih rendah atau sama dengan nilai kritis tabel Chi-Square dengan derajat bebas $\mathrm{df}=2$ dan alfa $=5 \%$ sebesar 5.99148. Tapi jika ternyata Jarque-Beralebih besar dari Chi-Square tabel maka berarti data tidak terdistribusi normal. 
Dari hasil uji normalitas dalam tabel 3 serta Residu pada gambar 1, dapat diketahui bahwa seluruh variabel RESIN, EVA, OCF dan Residumemiliki nilai Jarque Beralebih besar dari 5.99148. Sedang EARN memiliki nilai JarqueBeralebih besar dari 5.99148 Hasil ini menunjukkan bahwa hanya variabel EARN dapat dikatakan berdistribusi normal.

Walaupun distribusi data sebagian besar tidak normal, namun analisis dengan menggunakan model regresi linier berganda tetap dilanjutkan.Analisis regresi linier berganda memang mensyaratkan ada data yang terdistribusi normal agar menghasilkan Best Linear Unbiased Estimated (BLUE). Dengan kata lain, dari model tersebut digunakan untuk memprediksi yang akan menghasilkan estimasi yang tidak bias. Penelitian ini tidak melakukan estimasi tetapi hanya bertujuan untuk mengidentifikasi ada atau tidak ada pengaruh antara variabel-variabel independen terhadap variabel dependen.Inilah alasan mengapa analisis regresi ini tetap dilanjutkan.

\section{Uji Asumsi Klasik}

Hasil uji multikolinieritas dapat dilihat pada tabel 4 sebagai berikut :

Tabel 4

Uji Multikolinieritas

\begin{tabular}{c||cccc} 
& EARN & RESIN & EVA & OCF \\
\hline \hline EARN & 1.000000 & 0.353128 & 0.213966 & 0.325069 \\
RESIN & 0.353128 & 1.000000 & 0.472056 & 0.227170 \\
EVA & 0.213966 & 0.472056 & 1.000000 & 0.175793 \\
OCF & 0.325069 & 0.227170 & 0.175793 & 1.000000
\end{tabular}

Jika korelasi antara variabel bebas kurang dari 0.8 (rule of tumbs 0.8 ) maka dapat dikatakan tidak ada multicolinearity.Berdasarkan tabel 4, dapat diketahui bahwa seluruh variabel memiliki koefisien korelasi $<0,8$. Ini menandakan bahwa asumsi multikolinieritas terpenuhi.

\section{Uji Heteroskedastisitas}

Pengujian heteroskedastisitas dilakukan dengan menggunakan metode Glejser Test dengan hasil sebagaimana tampak pada Tabel 5 sebagai berikut :

Tabel 5

Uji Heteroskedatisitas 
White Heteroskedasticity Test:

\begin{tabular}{lrlr}
\hline \hline F-statistic & 1.238132 & Probability & 0.280755 \\
Obs*R-squared & $=\underline{9.848642}$
\end{tabular}

Berdasarkan Tabel 5 diatas, didapatkan nilai Obs*R-squared probability sebesar 0.275810 . Oleh karena $\mathrm{Obs}^{*} \mathrm{R}$-squared probability $>0,05$ maka dapat dikatakan tidak terdapat pelanggaran atas asumsi heteroskedastisitas.

\section{Analisis Regresi Berganda}

Hasil analisis regresi berganda terhadap model dapat dilihat pada Tabel 6 sebagai berikut :

Tabel 6

Hasil Analisis Regresi Berganda

Dependent Variable: RETURN

Method: Least Squares

Sample: 1160

Included observations: 160

\begin{tabular}{crllr}
\hline \hline Variable & Coefficien & Std. Error & t-Statistic & Prob. \\
& $\mathrm{t}$ & & & \\
\hline \hline C & -0.611729 & 0.186080 & -3.287449 & 0.0013 \\
EARN & 0.068818 & 0.032606 & 2.110613 & 0.0364 \\
EVA & 0.020346 & 0.012524 & 1.624613 & 0.1063 \\
RESIN & 0.020992 & 0.013243 & 1.585092 & 0.1150 \\
OCF & 0.031134 & 0.014713 & 2.116100 & 0.0359 \\
\hline \hline R-squared & 0.205226 & Mean dependent var & 0.344508 \\
Adjusted R-squared & 0.184716 & S.D. dependent var & 0.835195 \\
S.E. of regression & 0.754124 & Akaike info criterion & 2.304231 \\
Sum squared resid & 88.14890 & Schwarz criterion & 2.400330 \\
Log likelihood & -179.3385 & F-statistic & 10.00599 \\
Durbin-Watson stat & 1.861511 & Prob(F-statistic) & 0.000000 \\
\hline \hline
\end{tabular}

BerdasarkanTabel 6 diatas, maka dapat dituliskan model persamaan regresi sebagai berikut :

RET $=-0.611729+0.068818 \mathrm{EARN}+0.020346 \mathrm{EVA}+0.020992 \mathrm{RESIN}+0.031134 \mathrm{OCF}$ $+\mathrm{e}$
$(0.0364)$
$(0.1063)$
$(0.1150)(0.0359)$

Uji F 
Berdasarkan hasil sebagaimana tampak pada Tabel 6, didapatkan F statistik sebesar 10.00599dengan tingkat signifikansi sebesar 0,000. Oleh karena tingkat signifikansi < 0,05, maka dapat disimpulkan bahwa secara simultan Earnings,Economic Value Added, Residual Income, danOperation Cash Flowberpengaruh signifikan terhadap return.

Dengan hasil ini maka H1 yang menyatakan Earnings, Economic Value Added, Residual Income, danOperation Cash Flowberpengaruh signifikan terhadap return dapat diterima. Hasil penelitian ini mendukung penelitian Yudhira (2008) dan Mochtasom (2009) yang juga mendapatkan bukti secara statistik bahwa Earnings, Economic Value Added, Residual Income, danOperation Cash Flowberpengaruh signifikan terhadap return

\section{Adj. R Square}

Adj. R square pada penelitian ini sebesar 0.184716, menunjukkan bahwa sebesar 18,4716\% variabilitas Return dapat diterangkan oleh variabel Earnings, Economic Value Added, Residual Income, danOperation Cash Flow. Sedangkan sisanya sebesar $81.5284 \%$ dipengaruhi oleh faktor lain yang tidak digunakan dalam penelitian ini.

\section{Hasil Uji t}

\section{Earnings}

Variabel Earningsmemiliki t-uji sebesar 2.110613dengan tingkat probability sebesar0.0364. Oleh karena tingkat probability t-Statistic $<$ dari $\alpha_{0,05}$, maka dapat dikatakan bahwa Earningsberpengaruh positif signifikan terhadap return.

Hasil ini mengidikasikan bahwa laba perusahaan merupakan faktor penentu yang penting untuk menentukan harga pasar saham biasa, Data laba per saham sangat diperlukan bagi perusahaan dan investor sebagai alat informasi yang sangat penting.EPS merupakan rasio untuk mengukur berapa besar laba bersih yang dihasilkan perusahaan untuk tiap lembar saham yang baru. Sehingga dapat dipahami bila peningkatan pada earning perusahaan akan meningkatkan return saham. 
Dengan hasil ini, maka H1a yang menyatakan Earnings berpengaruh signifikanterhadap return yang diterima pemegang saham dapat diterima. Hasil penelitian ini konsisten dengan penelitian yang dilakukan Pradhono (2004), Yudhira (2008) dan Mochtasom (2009) yang juga dapat membuktikan secara statistik pengaruh EARNINGS terhadap return. 


\section{EVA}

Variabel EVA memiliki t-uji sebesar 1.624613 dengan tingkat signifikansi 0.1063. Oleh karena tingkat signifikansi $>$ dari $\alpha_{0,05}$, maka dapat dikatakan bahwa EVA tidak berpengaruh terhadap return.

Dengan hasil ini, maka H1b yang menyatakan Economic Value Added berpengaruh signifikanterhadap return ditolak. Hasil penelitian ini konsisten dengan penelitian yang dilakukan Pradhono (2004) dan Yudhira (2008) yang juga tidak dapat membuktikan secara statistik pengaruh EVA terhadap return.

Hasil ini mengindikasikan bahwa laba residual yang diukur dengan EVA tidak tepat untuk menjelaskan return saham di Bursa Efek Indonesia. Hal ini kemungkinan disebabkan dalam perhitungan EVA yang juga memasukkan faktor-faktor makro seperti suku bunga, sedang disisi lain kondisi perekonomian Indonesia pada periode tahun 2007-2009 yang tidak stabil membuat pergerakan suku bunga yang fluktuatif.

\section{RESIN}

Variabel RESINmemiliki t-uji sebesar 1.585092 dengan tingkat signifikansi 0.1150. Oleh karena tingkat signifikansi $>$ dari $\alpha_{0,05}$, maka dapat dikatakan bahwa RESINberpengaruh signifikan terhadap return. Ini mengindikasikan bahwa peningkatan pada RESINakan meningkatkan return saham.

Dengan hasil ini, maka H1c yang menyatakan Residual Income berpengaruh signifikanterhadap returnditolak.Hasil penelitian ini konsisten dengan penelitian yang dilakukan Pradhono (2004), Yudhira (2008) dan Mochtasom (2009) yang juga dapat membuktikan secara statistik pengaruh RESINterhadap return.

\section{OCF}

Variabel OCF memiliki t-uji sebesar 2.116100 dengan tingkat signifikansi 0.0359. Oleh karena tingkat signifikansi <dari $\alpha_{0,05}$, maka dapat dikatakan bahwa OCF berpengaruh signifikan terhadap return. 
Ini mengindikasikan bahwa dalam menentukan saham mana yang dibeli, seorang investor akan melihat perubahan laba serta tingkat cash flow perusahaan. Tingkat laba akan menunjukkan pertumbuhan investasi yang dilakukan dan tingkat cash flow mengindikasikan ukuran kegiatan operasi perusahaan. Hal ini mengakibatkan setiap publikasi informasi arus kas akan menimbulkan reaksi investor yang berdampak pula pada return saham. Sehingga dapat dipahami bila ukuran kegiatan operasi perusahaan semakin tinggi, maka akan berdampak pada peningkatan return perusahaan.

Dengan hasil ini, maka H1d yang menyatakan OCF berpengaruh signifikanterhadap return dapat diterima. Hasil penelitian ini konsisten dengan penelitian yang dilakukan Pradhono (2004), Yudhira (2008) dan Mochtasom (2009) yang juga dapat membuktikan secara statistik pengaruh OCF terhadap return.

\section{KESIMPULAN DAN SARAN}

\section{Kesimpulan}

Berdasarkan hasil analisis pada bab-bab sebelumnya maka dapat disimpulkan bahwa secara simultan Earnings, Economic Value Added, Residual Income, dan Operation Cash Flow berpengaruh signifikan terhadap return. Sedang secara parsial hanya Earnings dan Operation Cash Flow yang berpengaruh signifikan terhadap return.

\section{Saran}

Dengan uraian hasil penelitian di atas penulis mengemukakan beberapasaran. Pertama, untuk penelitian selanjutnya, diharapkan dapat mengembangkan variabel yang digunakan, misalnya dengan menambah variabel fundamental dan risiko (beta). Hal ini mengingat $\mathrm{R}$ Square yang didapat dari hasil analisis relatif kecil, yang menunjukkan bahwa masih banyak faktor-faktor di luar penelitian yang mempengaruhi return saham tetapi tidak digunakan dalam penelitian ini.

Kedua, pada penelitian yang akan datang diharapkan kriteria sampel perusahaan dapat diperluas lagi, sehingga hasil penelitiannya dapat digunakan pada obyek 
yang lebih luas. Dan ketiga, Investor hendaknya memperhatikan Earning dan

Operation Cash Flow sebelum menanamkan dananya,

\section{DAFTAR RUJUKAN}

Dewanto, H. 2005. Analisis Pengaruh Economic Value Added, Market Value Added, Residual Income, dan Cash Flow Op eration Terhadap Imbal Hasil Saham Sektor Pertambangan di BEJ 1995-2004. Tesis. Universitas Indonesia.

Djawahir, K.M. 2003. Sulitnya Menciptakan Nilai Tambah Bagi Shareholders .Swasembada, No. 22 Tahun XIX, hal.30-39.

Gadjah Mada International Journal of Business. 1999. Hubungan Antara EVAREVA Terhadap Pengembalian Saham. No. 22, hal.22-28.

Ho, et al. 2000. Does EVA Beat Earnings? Round 2: Evidence from Internet Companies. Unpublished.

Mirza, T. 1997. Economic Value Added Sebagai Alat Penilai. Manajemen dan Usahawan Indonesia. tp

Mundaryatiningsih, S. 2006. Analisis Pengaruh Kinerja Keuangan Perusahaan erhadap Kapitalisasi Pasar dan Return Saham Perusahaan Publik di Bursa Efek Jakarta .Tesis Institut Teknologi Bandung.

Mochtasom, Mochammad. 2009. Pengaruh Economic Value Added, Residual Income,Earnings, Arus Kas Operasi, Market Value Added Dan Roaterhadap Return Saham(Studi Pada Perusahaan Manufaktur Yang Listing Di BEI). Thesis.

Pradhono dan Yulius, J.C. 2004.Pengaruh Economic Value Added, Residual Income, Earnings dan Operation Cash Flow terhadap Return yang Diterima Pemegang Saham. Jurnal Akuntansi dan Keuangan, Vol. 6 (2), hal.140-165.

Ross, et al. 2002. Corporate Finance .Sixth Edition.McGraw-Hill. New York.

Stephen, F. O'Byine dan S. David Young. 2001. EVA dan Manajemen Berdasarkan Nilai (Panduan Praktis untuk Implementasi). PT. Salemba Empat Patria, Jakarta.

Triyono dan Jogiyanto, H.M. 2000. Hubungan Kandungan Informasi Arus Kas, komponen Arus Kas, dan Laba Akuntansi dengan Harga dan Return Saham . Jurnal Riset Akuntansi Indonesia, Vol. 3 (1), hal.54-68.

Utami, M. dan Rahayu, M. 2003. Peranan Profitabilitas, Suku Bunga, Inflasi dan nilai Tukar Dalam Mempengaruhi Pasar Modal Indonesia Selama Krisis Ekonomi. Jurnal Manajemen dan Kewirausahaan, Vol. 5 (2), hal.123-131.

Utomo, L.L. 1999. Economic Value Added Sebagai Ukuran Keberhasilan Kinerja manajemen Perusahaan. Jurnal Akuntansi dan Keuangan, Vol. 1 (1), hal.2842.

Waluyo, P.H., 2005. Pengaruh Return on Assets dan Economic Value Added Terhadap Tingkat Pengembalian Saham. Tesis. Universitas Sumatera Utara. 
Wibowo, Lasmono Eko. 2006. Penilaian Kinerja Keuangan Perusahaan dengan Metode Economic Value Added (EVA) (Study pada Perusahaan Farmasi yang Tercatat di Bursa Efek Jakarta). Skripsi. Universitas Muhammadiyah Malang.

Young, S.D. and O'MBrne, S.F. 2001. EVA and Value-Based Management: A Practical Guide to Implementation. McGraw-Hill Book Co. New York.

Yudhira, Ahmad, 2008. Pengaruh Economic Value Added, Residual Income, Earnings Dan cash Flow Operation Terhadap Stock Return Pada Perusahaan Manufaktur Di Bursa Efek Jakarta Tahun 2001-2006, 2008. Thesis. Univ. Sumatera Utara, 